This is the accepted version of the following article Salim, R. and Mawali, N. and Islam, A. 2014. Do the Intellectual Property Rights of Importers Matter for Promoting Australian Exports? The Australian Economic Review. 47 (3): pp. 279-289., which has been published in final form at http://doi.org/10.1111/1467-8462.12052 


\title{
DO INTELLECTUAL PROPERTY RIGHTS OF THE IMPORTERS MATTER FOR PROMOTING AUSTRALIAN EXPORTS?
}

\author{
Ruhul Salim $^{1} *$ Nasser Al Mawali $^{2}$, and Amirul Islam ${ }^{3}$ \\ ${ }^{1}$ School of Economics \& Finance, Curtin Business School, Curtin University, Perth \\ Australia \\ ${ }^{2}$ Department of Economics \& Finance, College of Economics and Political Science \\ (CEPS) \\ Sultan Qaboos University, P. O. Box No. 20, Al Khod 123, Muscat, OMAN \\ ${ }^{3}$ Department of Economics, University of Chittagong, Chittagong, Bangladesh
}

\begin{abstract}
This study provides the first empirical evidence on the effects of the intellectual property rights and threat of imitation on Australian export flows. Using data from Australia's all trading partners over the period 1995 to 2010 an augmented gravity is estimated in the context of an unbalanced panel. The empirical findings show that level of intellectual property rights of importing countries and threat of imitation posed by the importing countries are both sensitive to the Australian bilateral trade flows. These results, therefore, support the widely accepted positive nexus between the importance of intellectual property rights and bilateral trade flows.
\end{abstract}




\section{DO INTELLECTUAL PROPERTY RIGHTS OF THE IMPORTERS MATTER FOR PROMOTING AUSTRALIAN EXPORTS? ${ }^{1}$}

\section{Introduction}

The issue of intellectual property rights (IPRs) protection is gaining worldwide importance as economies move increasingly towards knowledge-based activities (Fink and Braga, 1999). Furthermore, the attention paid by trade economists to IPRs issues has recently increased especially after the inclusion of the Agreement on TradeRelated Aspects of Intellectual Property Rights (TRIPs) in the system of the World Trade Organization (Qui and Yu, 2010). Indeed, for the last two decades, the nature of linkages between intellectual property rights (IPRs) and international trade flows has been a source of much debate and controversy (Awokuse et al., 2010; Lerner, 2009). The debate is stimulated by the mixed empirical results of the effects of level of intellectual property rights on trade flows (Ivus, 2010).

The tension over strengthening IPRs stem from the fact that knowledge is nonrival in consumption (Arrow, 1962) and hence should be available free, but to produce such goods in the first place sufficient incentives need to be given to the innovators by way of intellectual property protection. As IPRs related laws differ across countries, it is of considerable interest from policy perspective to learn how changing the IPRs policies across countries or harmonizing them through multilateral initiatives, affect the cross country flow of goods and services that are embedded with invisible intellectual property element. Although there are a number of studies that have analysed the links between their protection and economic welfare, economic growth, innovations, FDI, and technology transfer ${ }^{2}$ a little empirical work has been done to directly investigate the relationship between export response and the IPRs protection in the destination countries.

\footnotetext{
${ }^{1}$ We are grateful to the anonymous referees and the editor of this journal for valuable comments and suggestions which tremendously improved the quality and presentation of the paper. However, the authors only are responsible for any remaining error.

2 For theoretical studies of IPRs and trade refer to: Flam and Helpman (1987), Schwartz (1991), and Taylor (1993). For studies of IPRs and innovation, refer to: Gangopadhyay and Mondal (2012), Lorenczik and Newiak (2012); Aoki and Prusa (1993), Diwan and Rodrik (1991), Helpman (1993), and Taylor (1994). Literature on IPRs, innovation, and economic growth, refer to: Branstetter et al., (2011); Grossman and Helpman (1991).
} 
Therefore, this study contributes to the existing literature by providing empirical evidence on the effects of the IPRs strength on bilateral exports of Australia. Furthermore, the study introduces a threat of imitation variable based on the research and development expenditure of the importers and interact this variable with the IPRs standard of the importers to empirically evaluate if the imitation threats in the destination countries matter for Australian exports. These issues have been investigated after controlling for the gravity related variables of trade and the country development status of the importers.

The organization of the paper proceeds as follows: Section 2 explains the link between intellectual property rights (IPRs), threat of imitation and trade flows. Empirical specification, methods and data are presented in Section 3. Section 4 presents the empirical results and analysis. The conclusions and some policy considerations are presented in the final section of the paper.

\section{IPRs, Threat of Imitation and Trade Flows: A Link}

The existing IPRs literature has identified two key channels through which status of the IPRs protection in a destination country affects the behaviour of foreign exporting firms when exporting to the destination country. The first of these is the "market expansion effect", and the second is the "market power effect". These effects explain how foreign exporting firms might react to a change of IPRs in an importing destination country. The market expansion effect is defined as a case in which strong foreign IPRs protection expands exports markets by ensuring exclusive rights to sell in the protected exports (Maskus \& Penubarti, 1995). An exporting firm may be expected to increase its sales (exports) to an importing country with strong IPRs protection and thereby expand its market for two reasons. Firstly, the exclusive rights provided to its exported goods through such strong protection reduce the capacity of local firms in a destination country to imitate the imported goods. The result is that the demand faced by the exporting firm is effectively shifted outward and larger sales volumes ensue. Secondly, strong IPRs protection in a destination country reduces the potential cost that may otherwise be incurred by foreign exporting firms in that it prevents the possible loss of their technologies to firms in the destination country. Such costs may include foregone revenues from reduced exports due to the 
availability of imitated products and the added burden of making products more difficult to reproduce ${ }^{3}$ (Smith, 1999, 2002; Taylor, 1993).

Alternatively, a foreign exporting firm may choose to react negatively to the strong IPRs protection in a destination country by restricting the quantity of its exports and increasing the unit price. This is known as the "market power effect" (Maskus \& Penubarti, 1995). There are also two reasons for a foreign exporting firm reacting negatively to strong IPRs protection in a destination country. Firstly, the market power that arises from such protection in an importing country causes the elasticity of demand facing the exporting firm to decrease. As a result, the exporting firm may choose to decrease its exports and increase its unit price in order to profit from the increased monopoly rents. Secondly, strong IPRs protection in an importing country raises the cost of imitation for local firms. It also raises their marginal cost because of measures required to avoid detection by the relevant regulatory authorities. Here, too, the exporting firm is encouraged to act monopolistically by reducing its exports to the destination country (Smith 1999, 2002).

It is also possible that strong IPRs change the preference structure of MNCs in favour of licensing and FDI activities and reduce incentive for direct arm's length exporting. Ferrantino (1993) shows that, countries with strong IPRs act to increase economic distance and thereby reduce international trade flows. However, the author finds transfer exports or export from parent to affiliate firms to rise in countries with weak IPRs. This finding weakens the argument that strong patent protection in the developing countries helps to protect the interest of the developed country firms and workers, especially when the cost of technology transfer from the parent to foreign affiliates is higher. Strong IPRs policies in the developing countries are likely to lead to vertical disintegration of the foreign firms. From the perspective of the developing countries, intra-firm trade among foreign firms may not be desirable in that it may involve tax-evasion through transfer pricing.

The market power and market expansion effects seem to offset each other; therefore, no clear theoretical prediction can be made about the impacts on the direction of trade in a world of varying IPRs protection regimes. All that can be

\footnotetext{
${ }^{3}$ The case in which exports of a firm are the consequence of strong IRPs protection in a destination country and the associated reduction in private expenditures to deter imitation by firms in a destination country is known as a cost-reduction effect (Taylor, 1993).
} 
inferred from the existing theory is that the pattern of a country's exports across importing countries depends on the relative importance of these two effects (Smith, 1999, 2002; Rafiquzzaman, 2002; Yang and Huang, 2009; Kazutaka,, 2012). Moreover, changes in the IPRs policies in the destination countries affect the behaviour of multinational firms in terms of their mode of serving the export market (Ferrantino, 1993). It is not certain how they will restructure their FDI, licensing and arm's length export policies in the new IPRs regime.

If imitative capacities of the trading partner (i.e. importing partner) are well developed due to large supply of scientists and engineers and high R\&D spending, then in the absence of the Intellectual Property Rights (IPRs), firms in the exporting country might be reluctant to sell (export) their goods under these conditions. Therefore, the imitative ability of the trading partner and its level of IPRs should be both taken into account in determining the ability of the importing country to imitate the imported goods. A country with high capacities to imitate (e.g. China), constitute a threat to other exporting countries that wants to export to China. Therefore, the presence and enforcement of IPRs in China is likely to be more important than in the case for a developing country such as Bangladesh which characterized by week imitative ability to imitate the imported goods. The imitative ability variable is measured in the literature by the percentage of R\&D expenditure to GDP (Smith, 1999).

While there have been useful modelling exercises in trade flows and IPRs linkages, there is hardly any application to Australia. However, there are few studies that analyse Australia's trade flows and trade competitiveness using the augmented gravity modelling. For example, Anderson (1995) examines Australia's changing trade pattern and growth performance and analyses the role of regional and global trade liberalization in affecting their changing trend in trade. Findlay and Song (1996) also analyse bilateral trade potential between Australia and china and argue that future bilateral trade between these two countries would continue to be driven by each country's comparative advantage. Sheng and Song (2008) examines the determinants of bilateral trade between Australia and China at the two digit commodity levels and demonstrate that current bilateral trade between these countries tends to promote the welfare of both countries in terms of generating more value added from exports. The most recent study conducted by Rahman (2012) demonstrates that Australia's bilateral trade is affected positively by economic size, per capita GDP, openness and common 
language, and negatively by the distance between the trading partners. The author also show that Australia has tremendous trade potential with Singapore, Argentina, the Russian Federation, Portugal, Greece, Chile, the Philippines, Norway, Brazil and Bangladesh. Whether this potential will still exist after imposing strong IPRs regime or their imitation threat status is certainly an interesting area of research.

The aforementioned discussion leads us to conclude that the question of whether strong IPRs in the importing countries would lead to increased imports or not from their import sources is a purely empirical question that can be answered through the empirical investigation only. In this regard, Australia is a suitable case study. Since the IPRs index covers among others the patentability of foods, plant and animal varieties, and Australia is a major exporter of these items, it is worthwhile to know how the varying strengths of the IPRs policies in the export market affects her export flows. Moreover, as both the developed and the developing countries, holding a wide spectrum of IPRs policies, are Australia's trading partners, the result obtained from the analysis will have more general applicability.

\section{Data, Methodology and Empirical Specification}

The study utilizes data from Australia's all trading partners over the period 1995 to 2010. Since the IPRs data are available only at five years interval and data for the R\&D expenditure are not available before 1995, four cross-sections, 1995, 2000, 2005, and 2010 have been selected for the study. The panel dataset has 830 observations and 223 countries that attract positive import from Australia. The countries with which Australia has export relationship with and their numbers vary over the years, and hence the dataset is an unbalanced panel.

The annual exports from Australia to her trading partners are from the UN COMTRADE database and the GDP data for the relevant countries are from the online database of the World Bank. The Geographical distance data $\left(\mathrm{D}_{\mathrm{ij}}\right)$ are obtained from a geo-distance database CEPII (Centre d'Etudes Prospectiveset d'Information Internationales), which is available at the www.cepii.com site. For the IPRs index, we have relied on two sources: the Ginerte-Park (1997) index for the period 1995 to 2005 and the Property Rights Alliance published, Property Rights Index 2010 Report, for the year 2010. These choices are based on data availability. The construction procedures for the IPRs indexes are slightly different in these two sources and they are published on different scales. The first ranges from 0 to 5 while the latter ranges 
from 0 to 10. In both cases, however, the higher value of the index implies higher IPRs protection. For conformity, the latter index was converted into the 0 to 5 scale by the formula, $(\mathrm{IPR} * 5) / 10$.

The tariffs are expressed as the simple mean of the most favoured nation (MFN) rates applied on all commodities, and are obtained from the World Development Indicators of the online database of the World Bank (http://databank.worldbank.org/). The research and development (R\&D) expenditure data, measured as the percentage of GDP, are from the UNESCO data centre (http://stats.uis.unesco.org/). The source does not have any data on the R\&D for any country before 1995. Inclusion of this variable in the construction of the imitation threat dummy has forced us to restrict our sample size from 1995 to 2010. Summary information about all the variables used in the study is provided in Table 1. From a cursory view of the table it can be surmised that, all of variables are non-normal and, except for the negatively skewed distance variable, all other variables are rightskewed and have distributions with positive kurtosis. Since the GDP, per capita GDP, and the R\&D are positively skewed, the countries with the below average income and below average $R \& D$ expenditure in the sample attract the higher amount of bilateral exports from Australia.

Table 1: Summary Statistics of the Selected Variables

\begin{tabular}{|c|c|c|c|c|c|c|c|}
\hline $\begin{array}{l}\text { Variables } \\
\text { Statistics }\end{array}$ & $\mathrm{Xij}$ & Yi & $Y j$ & YPj & Dij & IPRj & $\mathrm{RDj}$ \\
\hline Mean & 481.4 & 692.3 & 232.5 & 8863 & 12544 & 2.94 & 1.06 \\
\hline $\begin{array}{c}\text { Standard } \\
\text { Deviation }\end{array}$ & 2748.3 & 307.2 & 1009.4 & 14019 & 4117 & 0.97 & 0.97 \\
\hline Skewness & 12.94 & 0.66 & 9.23 & 2.66 & -0.93 & 0.06 & 1.24 \\
\hline Kurtosis & 208 & 1.83 & 106 & 11.82 & 2.81 & 2.27 & 3.99 \\
\hline Normality $^{1}$ & $\begin{array}{c}6159 \\
(<0.01)\end{array}$ & $\begin{array}{c}27.34 \\
(<0.01)\end{array}$ & $\begin{array}{c}10060 \\
(<0.01)\end{array}$ & $\begin{array}{c}198 \\
(<0.01)\end{array}$ & $\begin{array}{c}70.92 \\
(<0.01)\end{array}$ & $\begin{array}{c}12.67 \\
(<0.01)\end{array}$ & $\begin{array}{c}37.84 \\
(<0.01)\end{array}$ \\
\hline
\end{tabular}

Note: Variables: Xij-Exports (Millions of US dollars), Yi-Exporter's (Australia's) GDP (Billions of US dollars), Yj - Importers' GDP (Billions of US dollars), YPj - Importers' Per Capita GDP (US dollars), Dij-Bilateral Distance (Kilometres), IPRj-Importers' IPRs Index (0 to 5 scale), RDjResearch and Development Expenditure (Percentage of GDP). ${ }^{1}$ Jarque-Berra statistics ( $p$-value in parenthesis)

Many observations on the IPRs index and the $R \& D$ variables for the selected countries in the sample are not available in the data source consulted. Since these 
countries have information on other variables, multiple imputation method, as suggested in Honaker et al (2011), has been used to infer about the missing data. The technique involves specifying a conditional predictive distribution for the missing values based on the observed data, and then drawing values from the posterior distribution,

$$
f\left(\theta \mid Z_{0}\right)=\int f\left(\theta \mid Z_{0}, Z_{M}\right) f\left(Z_{M} \mid Z_{0}\right) d Z_{M},
$$

where $\theta$ is the parameter vector of the distribution. $Z_{O}$ and $Z_{M}$ are respectively the sets of observed and missing values in the data matrix. In our sample the R\&D and the IPRs variable have many missing values. As part of the post-imputation diagnostic, the distributions of the observed and imputed data for these two variables are reported in Figure 1. Though the distributions for the imputed values do not perfectly synchronize with the distributions for the observed values for these two variables,

\section{Figure 1: Comparison of the distributions of the observed}

\section{and the imputed data}
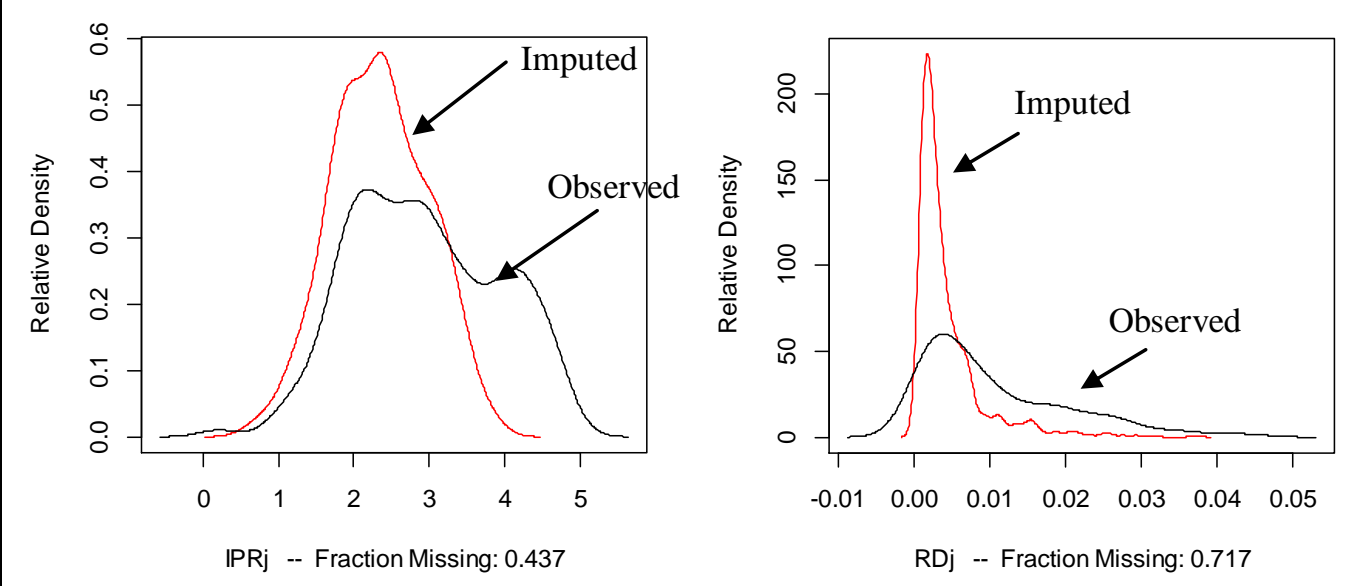

they certainly have an impulse to lean toward the observed distributions. As these imputed data are randomly generated from predictive distributions of the variables, they are amenable to undergo any statistical procedure like the observed data. Inclusion of the imputed data with the observed data has been found to improve the precision of the estimates.

The analysis of the study is based on an augmented version of the gravity model, similar to the one used by Silva and Nelson (2012). The basic form of the 
model can be traced back to the Anderson and van Wincoop (2003) paper, where the equations of the model are derived from theoretical foundations, and the idea of multilateral resistance to trade is introduced. The implication of the model is that, two trading partners' bilateral trade depends not only on their bilateral resistances (such as, tariffs, distance, IPRs, etc), but also on their obstacles to trade with other trading partners. In other words, it is the relative barriers that matters for bilateral trade. The theoretical gravity model derived in Anderson and van Wincoop (2003) is:

$$
\begin{aligned}
X_{i j} & =\left(\frac{Y_{i} Y_{j}}{Y_{T}}\right)\left(\frac{t_{i j}}{\Pi_{i} P_{j}}\right)^{1-\sigma}, \text { where } \\
\Pi_{i} & =\left[\sum_{j=1}^{N}\left(\theta_{j} / t_{i j}\right) P_{j}{ }^{\sigma-1}\right]^{1 /(1-\sigma)} \\
P_{j} & =\left[\sum_{j=1}^{N}\left(\theta_{i} / t_{i j}\right) \Pi_{i}{ }^{\sigma-1}\right]^{1 /(1-\sigma)}
\end{aligned}
$$

The term $t_{i j}$ is the unobserved border effect, and $\Pi_{i}$ and $P_{j}$ are the multilateral prices, also unobserved. Solving model (1) requires customized non-linear program. There are, however, some simpler alternatives to solving the complicated non-linear equation. Baier and Bergstrand (2009), for example, propose a linearized version of the model based on an approximation from the Taylor series expansion. Their extensive Monte-Carlo experiments show that the results from the linear and nonlinear versions of these models are quite close. Feenstra (2004), and Baldwin and Taglioni (2006) suggest for incorporating country fixed effects for importers and exporters in the gravity equation to control for the multilateral resistance term. This latter approach is simpler and we follow it without the exporter fixed effect, as our interest is in Australian exports only. The model to be estimated in our context is:

$$
\begin{aligned}
\ln X_{i j t}= & \beta_{0}+\beta_{1} \ln Y_{i t}+\beta_{2} \ln Y_{j t}+\beta_{3} \ln D_{i j}+\beta_{4} I P R_{j t}+ \\
& \beta_{5} S T_{j t}+\beta_{6}\left(S T_{j t} \times I P R_{j t}\right)+\beta_{7} H I_{j t}+\beta_{8} M I_{j t}+\varepsilon_{i j t} \\
& i \in \text { Exporter(Australia), } j \in \text { importers, } t \in \text { Time }
\end{aligned}
$$

Where $X_{i j t}$ is the annual export of country i (here Australia) to its trading partner $\mathrm{j}$ in year $\mathrm{t}$. The basic gravitational variables that appear as independent variables in this study are market sizes of the trading partners $\left(\mathrm{Y}_{\mathrm{it}}\right.$ and $\left.\mathrm{Y}_{\mathrm{jt}}\right)$ and the geographical distances between them $\left(\mathrm{D}_{\mathrm{ij}}\right)$. The theoretical gravity model dictates 
what variables should be included in the model and how they need to be measured. As a guideline, Shephard (2012) suggests that the dependent variable should be the log of bilateral exports, not total trade, and GDPs be measured in nominal terms, not in real terms. The two unobserved multilateral price terms, $P_{i}$ and $\Pi_{j}$, included in the model effectively deflate the data. It is not even appropriate to include the observed price indices in the model.

Two categorical variables have been created to examine how their various levels affect the Australian exports, and how they interact with the IPRs of the importers in modifying the response of these export flows. The first one is the imitation threat with two levels: strong and weak. It is believed that countries that spend more on research have better capabilities to make counterfeit products. To discover if there is any threshold point in the $R \& D$ expenditure beyond which countries are in the strong imitative ability group, the following regression equation is fitted:

$$
\ln \left(X_{i j t}\right)=\beta Z+\delta\left(R D_{j t}-\psi\right) \times I\left(R D_{j}>\psi\right)+\varepsilon_{i j t}
$$

where $\psi$ is the regime switching point in the research and expenditure variable (RDj) and $\mathrm{Z}$ includes all other independent controls used in equation (2). I(.) is an indicator function that equals one if the condition inside the bracket is satisfied and zero otherwise. The equation is estimated using the Muggeo (2003) proposed segmented regression method, whereby a broken line relationship is fitted to the data to find the break point. The application of this method yields an estimated breakpoint near 0.64 with a standard error of 0.18 and hence the breakpoint is statistically significant. The imitation capability dummy is created based on this cut-off point. Countries in the strong imitation threat (ST) group have R\&D expenditure above 0.64 per cent of their GDPs while others are in the weak imitation threat group. As a robustness check, the cut-off point has also been taken as the medium value of the $\mathrm{R} \& \mathrm{D}$ expenditure and the results are compared.

The second categorical variable is the development status of the countries based on their per capita income. World Bank followed classifications for income groups are used here for this purpose. Countries with per capita income of US\$1,025 or less are considered in the low income group, per capita income in the range of US\$ 1,026 to 12,475 are in the middle income (MI) group, and with per capita income more than US\$12,476 are in the high income (HI) categories. The weak threat group 
and the low income group are treated as the reference categories, against which the influences of the other categories are evaluated.

\section{Empirical Results and Analysis}

For analysing the effect of the IPRs protection and its potential interaction with the imitation threat status of the importers, model (2) has been estimated first without the imitation threat dummy (Model 2a) and then with the imitation threat dummy (Model $2 b)$. The empirical results from these two models are reported in Table 2 for both the imputed and the observed-only dataset. The model fit statistics, adjusted $\mathrm{R}^{2}$, reported at the bottom of the table indicate that both datasets fit the model well. However the degrees of freedom are severely reduced in the dataset with missing observations, and coefficients on some of the variables such as the distance and importers' income status turn out as insignificant. The problem is that, though these two variables rarely have missing observations, unavailability of many observations on the $R \& D$ expenditure and the IPRs variables (around 72 per cent and 42 per cent of the observations are missing for the R\&D and the IPRs of the importers in the sample) force list-wise deletion on the dataset and waste valuable information inherent in other variables. The results of the model are hence explained in terms of the imputed dataset and the results from the observed dataset are reported alongside for comparison purpose only.

The coefficient estimates are accompanied below them by their cluster-robust standard errors. As the export flows are considered over periods, some country pairs appear several times in the dataset. The error terms for such set of country pairs are likely to be correlated. These observations have been treated as a group on the basis of their distance and the cluster robust standard errors are reported for the estimated coefficients. Generally, the overall performances of the basic gravity variables are quite satisfactory in terms of their statistical significance and econometric interpretation. While geographical distance reduces total trade, greater market sizes of both the source and the destination countries expand them. Exporter's income has stronger impact than importers' income $(0.70$ versus 0.47$)$ in the estimated export trade flow equation and their combined effect is higher than one. Thus it can be expected that the Australian export performance will be tied up with the global economic fluctuations. 
Table 2: Estimation Results

(Dependent Variable: Log of Total Export)

\begin{tabular}{|c|c|c|c|c|c|c|c|c|c|}
\hline \multirow{3}{*}{ Variables } & \multirow{3}{*}{ Description } & \multicolumn{4}{|c|}{ Imitation Threat at $\mathrm{RDj}=0.64$} & \multicolumn{4}{|c|}{ Imitation Threat at the median RDj } \\
\hline & & \multicolumn{2}{|c|}{ Imputed Dataset } & \multicolumn{2}{|c|}{ Observed Dataset } & \multicolumn{2}{|c|}{ Imputed Dataset } & \multicolumn{2}{|c|}{ Observed Dataset } \\
\hline & & Model 2a & Model 2b & Model 2a & Model 2b & Model 2a & Model 2b & Model 2a & Model $2 b$ \\
\hline Constant & Intercept & $\begin{array}{c}9.80 \\
(7.94)\end{array}$ & $\begin{array}{c}9.61 \\
(7.96)\end{array}$ & $\begin{array}{c}-9.74 \\
(31.83)\end{array}$ & $\begin{array}{l}-28.81 \\
(33.86)\end{array}$ & $\begin{array}{c}9.80 \\
(7.94)\end{array}$ & $\begin{array}{l}10.17 \\
(7.93)\end{array}$ & $\begin{array}{c}-9.75 \\
(31.83)\end{array}$ & $\begin{array}{l}-32.70 \\
(34.52)\end{array}$ \\
\hline $\log (\mathrm{Yi})$ & $\begin{array}{l}\text { Log of Exporter's } \\
\text { income }\end{array}$ & $\begin{array}{l}0.70 * * \\
(0.11)\end{array}$ & $\begin{array}{l}0.70 * * \\
(0.11)\end{array}$ & $\begin{array}{l}0.40^{*} \\
(0.24)\end{array}$ & $\begin{array}{l}0.74 * * \\
(0.32)\end{array}$ & $\begin{array}{l}0.70 * * \\
(0.11)\end{array}$ & $\begin{array}{l}0.70 * * \\
(0.11)\end{array}$ & $\begin{array}{l}0.40 * \\
(0.24)\end{array}$ & $\begin{array}{l}0.78 * * \\
(0.34)\end{array}$ \\
\hline $\log (Y j)$ & $\begin{array}{l}\text { Log of Importers } \\
\text { income }\end{array}$ & $\begin{array}{l}0.47 * * \\
(0.08)\end{array}$ & $\begin{array}{l}0.48 * * \\
(0.07)\end{array}$ & $\begin{array}{l}0.78 * * \\
(0.27)\end{array}$ & $\begin{array}{c}0.22 \\
(0.31)\end{array}$ & $\begin{array}{c}0.47 * * \\
(0.08)\end{array}$ & $\begin{array}{c}0.50 * * \\
(0.08)\end{array}$ & $\begin{array}{l}0.78 * * \\
(0.27)\end{array}$ & $\begin{array}{c}0.21 \\
(0.31)\end{array}$ \\
\hline $\log (\mathrm{Dij})$ & $\begin{array}{l}\text { Distance between } \\
\text { Trading Partners }\end{array}$ & $\begin{array}{c}-2.73 * * \\
(0.82)\end{array}$ & $\begin{array}{c}-2.70 * * \\
(0.83)\end{array}$ & $\begin{array}{l}-0.39 \\
(3.35)\end{array}$ & $\begin{array}{c}1.92 \\
(3.56)\end{array}$ & $\begin{array}{c}-2.73 * * \\
(0.82)\end{array}$ & $\begin{array}{c}-2.80 * * \\
(0.82)\end{array}$ & $\begin{array}{l}-0.39 \\
(3.35)\end{array}$ & $\begin{array}{c}2.28 \\
(3.59)\end{array}$ \\
\hline $\mathrm{Tj}$ & Importers' Tariffs & $\begin{array}{c}0.008 \\
(0.006)\end{array}$ & $\begin{array}{c}0.008 \\
(0.006)\end{array}$ & $\begin{array}{l}-0.005 \\
(0.009)\end{array}$ & $\begin{array}{c}0.034 \\
(0.036)\end{array}$ & $\begin{array}{c}0.008 \\
(0.006)\end{array}$ & $\begin{array}{c}0.008 \\
(0.006)\end{array}$ & $\begin{array}{l}-0.005 \\
(0.009)\end{array}$ & $\begin{array}{c}0.031 \\
(0.035)\end{array}$ \\
\hline IPRj & Importer's IPR & $\begin{array}{l}0.17 * * \\
(0.06)\end{array}$ & $\begin{array}{l}0.15 * * \\
(0.07)\end{array}$ & $\begin{array}{l}0.21 * * \\
(0.10)\end{array}$ & $\begin{array}{l}0.32 * \\
(0.19)\end{array}$ & $\begin{array}{l}0.17 * * \\
(0.06)\end{array}$ & $\begin{array}{l}0.18 * * \\
(0.21)\end{array}$ & $\begin{array}{l}0.21 * * \\
(0.10)\end{array}$ & $\begin{array}{l}0.28 * \\
(0.16)\end{array}$ \\
\hline $\mathrm{STj}$ & $\begin{array}{c}\text { Imitation Threat } \\
\text { Dummy }\end{array}$ & --- & $\begin{array}{l}-0.22 \\
(0.47)\end{array}$ & -- & $\begin{array}{c}0.19 \\
(0.95)\end{array}$ & --- & $\begin{array}{l}-0.21 \\
(0.33)\end{array}$ & --- & $\begin{array}{l}-0.37 \\
(0.95)\end{array}$ \\
\hline $\mathrm{IPRj} \times \mathrm{ST} \mathrm{j}$ & $\begin{array}{l}\text { Interaction between } \\
\text { IPRj and } \mathrm{STj}^{\mathrm{T}}\end{array}$ & --- & $\begin{array}{c}0.09 \\
(0.15)\end{array}$ & --- & $\begin{array}{l}-0.02 \\
(0.26)\end{array}$ & --- & $\begin{array}{l}-0.009 \\
(0.112)\end{array}$ & --- & $\begin{array}{c}0.10 \\
(0.27)\end{array}$ \\
\hline $\mathrm{HIj}$ & High Income Dummy & $\begin{array}{l}0.52 * * \\
(0.25)\end{array}$ & $\begin{array}{l}0.52 * * \\
(0.25)\end{array}$ & $\begin{array}{l}-0.09 \\
(0.42)\end{array}$ & $\begin{array}{c}0.43 \\
(0.74)\end{array}$ & $\begin{array}{l}0.52 * * \\
(0.25)\end{array}$ & $\begin{array}{l}0.60 * * \\
(0.25)\end{array}$ & $\begin{array}{l}-0.09 \\
(0.41)\end{array}$ & $\begin{array}{c}0.37 \\
(0.75)\end{array}$ \\
\hline $\mathrm{MIj}$ & $\begin{array}{l}\text { Medium Income } \\
\text { Dummy }\end{array}$ & $\begin{array}{l}0.45^{* *} \\
(0.14)\end{array}$ & $\begin{array}{l}0.45^{* *} \\
(0.15)\end{array}$ & $\begin{array}{c}0.32 \\
(0.27)\end{array}$ & $\begin{array}{c}0.72 \\
(0.64)\end{array}$ & $\begin{array}{c}0.45^{* *} \\
(0.14)\end{array}$ & $\begin{array}{l}0.49 * * \\
(0.15)\end{array}$ & $\begin{array}{c}0.32 \\
(0.28)\end{array}$ & $\begin{array}{c}0.67 \\
(0.64)\end{array}$ \\
\hline Adjusted $\mathrm{R}^{2}$ & --- & 0.91 & 0.91 & 0.94 & 0.95 & 0.91 & 0.91 & 0.94 & 0.95 \\
\hline
\end{tabular}

Notes: ** and * indicate statistically significant estimates at 5 per cent and 10 per cent levels respectively.

The estimates are obtained after controlling for the importer-fixed effect. Figures inside the parentheses are cluster-robust standard errors. 
The main interest of this paper is to determine whether the bilateral exports of Australia are sensitive to the differences in IPRs protection in the destination countries, and the extent to which the imitation threat interacts with the IPRs variable in affecting Australian exports. Since model (2a) does not have the imitation threat status dummy in it, the coefficient of the IPRs in this model reflect the impact of the IPRs strength of all countries in the sample on the export flow of Australia. The estimated coefficient 0.17 is significant at the conventional 5 per cent level, implying that a one point higher score of the importers in the IPRs scale can lead to about 17 per cent increase in bilateral exports from Australia. Thus the result suggests the dominance of the market expansion effect of the IPRs strength of the importers for Australian exports.

However, the presence of imitation threat in terms of the importers' $R \& D$ expenditure (Model 2b) does not seem to have any statistically significant effect on Australia's bilateral exports. The combination of strong imitation threat and high IPRs is similarly insignificant in affecting Australian exports. In case of the country income status, both the high income group and the medium income group import more, by about 44 per cent and 49 per cent respectively, compared to the low income group. Since many trading partners of Australia are developing countries and come from the middle income group, the result conforms to the findings of Maskus and Penubarti (1995) who also show that the effect of patent protection is stronger in developing countries.

China, the top ranking trading partner of Australia, has around one per cent of GDP in the research and development expenditure and is showing rising IPR index over time in the sample. China's bilateral trade with Australia is also positively responding at the same time. Similar explanation applies for trade between Australia and India. Whatever may be the level of imitation threat, when considered as a whole, the regression result shows that it is in the interest of Australia to have strong IPRs protection in the partner trading countries. Presence of the imitation threat and its interaction with the IPRs do not matter. However, in the context of US manufacturing data Smith (1999) presents a mixed result by showing that patent right barriers adversely affect trade for high imitation threat group but increases trade with low or moderate imitation threat group. 
It is not surprising to find that a non-high technology product exporter like Australia enjoys positive export response from higher IPRs protection in the destination countries. In a cross section of 89 countries, Fink and Braga (2005), for example, find that non-fuel category aggregate export responds positively while high technology product suffers from higher IPRs in the partner countries. Their argument is that high technology firms may have tendencies to exploit market power and serve foreign market through FDI when IPRs in the importing countries are stronger. Stern (1987) argues that making IPRs regime strong is similar to removing non-tariff barriers. Exporters have to worry less about the counterfeiting of their products and can reduce expenditure on making the product less imitable.

The influence of intellectual property rights in positively affecting trade flow is in conformity with the growing importance of knowledge based economy. According to an estimate of the Australian Bureau of Statistics, the value of intellectual property in Australia in 2010-2011 was worth $\$ 182.5$ billion and trade royalties associated with intellectual property amounted to $\$ 1.1$ billion and $\$ 5.2$ billion from export and import respectively (Department of foreign Affairs and Trade, 2012). Moreover, it is often argued that intellectual property policy reforms in developing countries can raise their inward foreign direct investment flow (Park, 2008) and increase imports by the affiliates from their mother countries. There is, however, a fear among the developing countries that their technologies are mostly imitative and adoptive in nature and hence strong IPRs in the home countries would imply benefiting foreign firms in the developed countries at the expense of the local firms in the developing countries. Since strict property right and innovation activities are complementary (Schneider, 2005) supporting research and development activities in the developing countries by the developed world can result in a win-win situation.

\section{Conclusion}

An explicit econometric analysis of the relationship between the level of intellectual property rights, imitation threat, income status, and bilateral export flows from Australia to her trading partners has been performed, and the notion that the level of intellectual property rights stimulate bilateral export flows from Australia has been supported. In particular, the results show that stronger IPRs regimes irrespective of imitation threat make commodities more tradable, as far as the Australian exports are 
concerned. The results are based on about 830 observations on Australia's trading partners, spread over four cross sections, and should be credible.

Positive relationship between the IPRs in the importing country and the exports flows to that country has important policy implications for reducing knowledge gaps between the developed and the developing countries. Instead of letting the developing countries follow the learning-by-imitating strategy, in a lax IPRs environment, knowledge transfer should take place through direct technical assistance. Countries that are beneficiaries of the strong IPRs regime can share their gains by allowing the affected countries increased market access through special tariff concessions like the generalized system of preferences. This will make the goal of achieving higher IPRs standard and increased export flow simultaneously easier. Alternatively, technology transfer can take place through increased FDI activities and building institution (research and training) to enhance the absorptive capacity of the host countries.

The study is, however, Australia focused and based on aggregate trade data that might conceal various response patterns to property rights reform depending on industry categories. Future research in this area can replicate similar analysis based on more extensive datasets and use industry-specific data, which will help to check whether the results of the present study are representative. Another important dimension of the IPRs policy changes, namely, its effects on the welfare of the source and destination countries or the world as a whole, was not covered in the study. Obviously, there are payoffs from directing future research attention in this highly debated area of the intellectual property protection. 


\section{References}

Anderson, J. E., and E. v. Wincoop. (2003), Gravity with Gravitas: A Solution to the Border Puzzle. American Economic Review 93 (1): 170-192.

Anderson, K. (1995) Australia's Changing trade pattern and growth performance in R. Pomfret (ed.), Australia's Trade Policies, (Melbourne: Oxford University Press): 1-5.

Aoki, R. and Prusa, T. (1993) International Standards for Intellectual Property Protection and R\&D Incentives, Journal of International Economics, 35: 251-273.

Arrow, K.J., (1962), Economic Welfare and the Allocation of Resources for Invention, in R.R. Nelson (ed.), The Rate and Direction of Inventive Activity, Princeton: Princeton University Press, pp. 609-625.

Awokuse, Titus O. and H. Yin, (2010), Does Stronger Intellectual Property Rights Protection Induce More Bilateral Trade? Evidence from China's Imports. World Development, 38: 1094-1104.

Baier, S. L., and J. H. Bergstrand. (2009), Bonus vetus OLS: A simple method for approximating international trade-cost effects using the gravity equation. Journal of International Economics 77: 77-85.

Baldwin, R., and D. Taglioni. (2006), Gravity for dummies and dummies for gravity equations. National Bureau of Economic Research Working Paper 12516, NBER.

Branstetter, L., Fisman, R., Foley, F. C. and Saggi, K. (2011) Does intellectual propertyrights reform spur industrial development? Journal of International Economics, 83: 27-36.

Diwan, I. and Rodrick, D. (1991) Patents, appropriate technology, and north-south trade, Journal of International Economics, 30: 27-48.

Falm, H. and Helpman, E. (1987) Industrial policy under monopolistic competition, Journal of International Economics, 22: 79-102.

Feenstra, R. C. (2004), Advanced International Trade: Theory and Evidence: Princeton University Press.

Ferrantino, Michael J. (1993), The Effect of Intellectual Property Rights on International Trade and Investment, Weltwirtschaftliches Archiv, 129: 300-331.

Findlay, C. and Song, L. (1996) The China-Australia commodity trade:1985-94 in C. MacKerras (ed.) Australia and China: Patterns in Asia (Sydney: MacMillan): 90-112.

Fink, Carsten \& Braga, Carlos A. Primo, (1999), How stronger protection of intellectual property rights affects international trade flows, Policy Research Working Paper Series 2051, The World Bank.

Fink, Carsten \& Braga, Carlos A. Primo, (2005), "How stronger protection of intellectual property rights affects international trade flows," in C. Fink and K. E.

Gangopadhyay, K., \& Mondal, D., (2012), Does stronger protection of intellectual property stimulate innovation? Economics Letters, 116 (1): 80-82

Ginarte, J.C. and Park, W. (1997), "Determinants of patent rights: A cross-national study", Research Policy, 26: 283-301.

Grossman, G. M. and Helpman, E. (1991) Innovation and Growth in the Global Economy, MIT Press, Cambridge 
Helpman, E. (1993) Innovation, imitation, and intellectual property rights, Econometrica, 61: 1247-1280.

Honaker, James, Gary King, and Matthew Blackwell. (2011), Amelia II: A Program for Missing Data, Journal of Statistical Software no. 45(7): 1-47.

Ivus, O., (2010), Do stronger patent rights raise high-tech exports to the developing world?" Journal of International Economics, 81: 38-47.

Kazutaka, K., (2012), Negative Effects of Intellectual Property Protection: The unusual suspects?, RIETI Discussion Paper Series 12-E-057; Hosei University, Tokyo.

Lerner, J., (2009), The Empirical Impact of Intellectual Property Rights on Innovation: Puzzles and Clues, American Economic Review (Papers \& Proceedings), 99(2): 343-348.

Lorenczik, C., and Newaik, M. (2012), Imitation and innovation driven development under imperfect intellectual property rights, European Economic Review, 7: 13611375.

Muggeo, V. 2003. Estimating regression models with unknown break-points. Statistics in Medicine 22: 3055-3071.

Maskus, K.E. and Penubarti, M. (1995), How trade-related intellectual property rights?, Journal of International Economics, 39: 227-248.

Park, W. G (2008) International patent protection: 1960-2005, Research Policy, 37:761-766.

Qui, L., \& Yu, H. (2010), Does the protection of foreign intellectual property rights stimulate innovation in the US?, Review of International Economics, 18(5): 882-895.

Rafiquzzaman, M. (2002) The impact of patent rights on international trade: evidence from Canada, Canadian Journal of Economics, 35:307-330.

Rahman, M. (2012) Exploring Australia's global trade potential: a gravity approach with panel data, Academy of Taiwan Business Management Review, 8(1). pp. 35-47.

Schneider, P. H. (2005) International trade, economic growth and intellectual property rights: A panel data study of developed and developing countries, Journal of Development Economics, 78: 529-547.

Schwartz, M. (1991) Patent protection through discriminatory exclusion of imports, Review of Industrial Organization, 6: 231-246.

Sheng, Y. and Song, L. (2008) Comparative Advantage and Australia-China bilateral trade, Economic Papers, 27(1): 41-56.

Shepherd, B. (2012), The Gravity Model of International Trade: A User Guide. ARTNeT Gravity Modeling Initiative, UNDP.

Silva, J., and Nelson, D., (2012), " Does Aid Cause Trade? Evidence from an Asymmetric Gravity Model", The World Economy, 35 (5): 545-577.

Smith, P. J. (2002) Patent Rights and Trade: Analysis of Biological Products, Medicinals and Botanicals, and Pharmaceuticals, American Journal of Agricultural Economics, 84:495-512. 
Smith, P.J. (1999), Are patent rights a barrier to US exports?, Journal of International Economics, 48:151-177.

Stern, R. (1987), "Intellectual Property", in Finger and Olechowski (eds), The Uruguay Round: A Handbook of Multilateral Negotiations, The World Bank, Washington D.C.

Taylor, M. S. (1993) Trips, Trade, and Technology Transfer, Canadian Journal of Economics 26: 625-637.

Taylor, M. S. (1994) Trips, trade, and technology transfer, International Economic Review, 35: 361-381.

Yang, H. and Huang, J. (2009) Do intellectual property rights matters to Taiwans's exports: A Dynamic panel approach, Pacific Economic Review, 14(4): 555-57. 